Prepared in cooperation with the Alaska Department of Environmental Conservation

\title{
Water Quality in the Tanana River Basin, Alaska, Water Years 2004-2006
}

Open-File Report 2007-1390 



\section{Water Quality in the Tanana River Basin, Alaska, Water Years 2004-06}

By Edward H. Moran

Prepared in cooperation with the

Alaska Department of Environmental Conservation

Open-File Report 2007-1390 


\title{
U.S. Department of the Interior DIRK KEMPTHORNE, Secretary
}

\author{
U.S. Geological Survey \\ Mark D. Myers, Director
}

\section{U.S. Geological Survey, Reston, Virginia: 2007}

For product and ordering information:

World Wide Web: http://www.usgs.gov/pubprod

Telephone: 1-888-ASK-USGS

For more information on the USGS--the Federal source for science about the Earth, its natural and living resources, natural hazards, and the environment:

World Wide Web: http://www.usgs.gov

Telephone: 1-888-ASK-USGS

Any use of trade, product, or firm names is for descriptive purposes only and does not imply endorsement by the U.S. Government.

Although this report is in the public domain, permission must be secured from the individual copyright owners to reproduce any copyrighted materials contained within this report.

Suggested citation:

Moran, E.H., 2007, Water quality in the Tanana River basin, Alaska, water years 2004-06: U.S. Geological Survey Open-File Report 2007-1390, 6 p. 


\section{Contents}

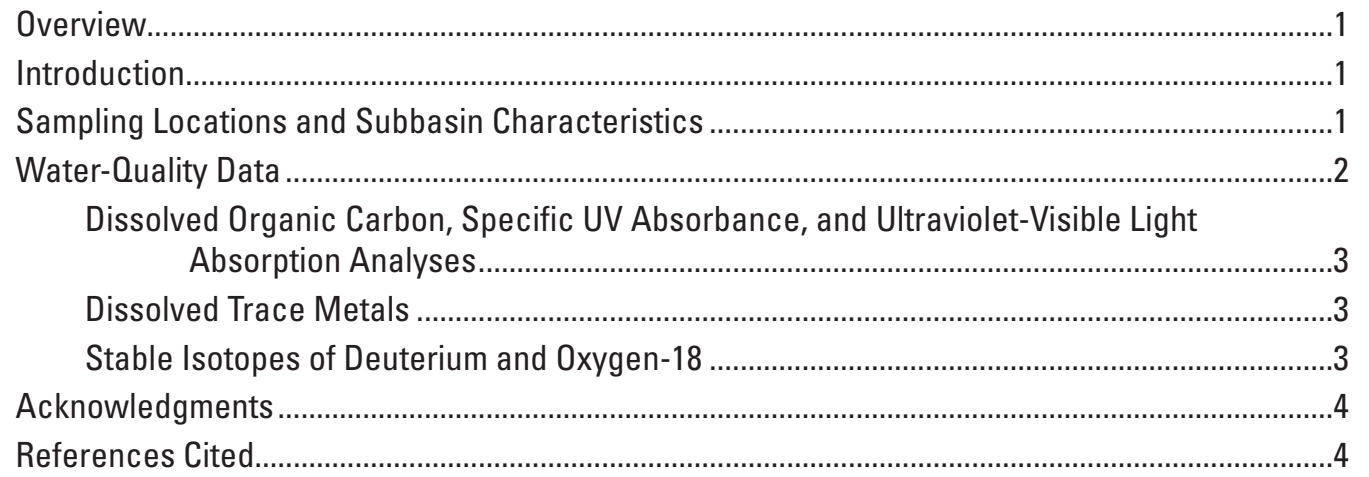

\section{Figures}

Figure 1. Map showing location of water-quality sampling sites in the Tanana River basin, Alaska ..............................................................

\section{Tables}

Table 1. Summary of site characteristics at sampling locations in the Tanana River

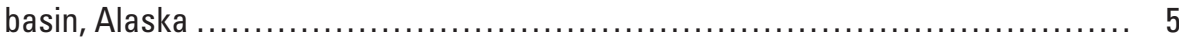

Table 2. Basin characteristics of sampled subbasins in the Tanana River basin, Alaska . . 5

Table 3. Summary of standard analytical methods and references $\ldots \ldots \ldots \ldots \ldots \ldots \ldots \ldots$

Table 4. Water-quality data for sites sampled in 2004 in the Tanana River basin, Alaska . . 5

Table 5. Water-quality data for sites sampled in 2005 in the Tanana River basin, Alaska . . 5

Table 6. Water-quality data for sites sampled in 2006 in the Tanana River basin, Alaska . . 5 


\section{Conversion Factors, Datums, and Abbreviations}

Conversion Factors

\begin{tabular}{lll}
\hline Multiply & \multicolumn{1}{c}{ By } & To obtain \\
\hline Length & \\
\hline millimeter $(\mathrm{mm})$ & $3.937 \times 10^{-2}$ & inch \\
centimeter $(\mathrm{cm})$ & $3.937 \times 10^{-1}$ & $\begin{array}{l}\text { inch } \\
\text { meter }(\mathrm{m})\end{array}$ \\
\hline & 3.281 & \\
\hline square kilometer $\left(\mathrm{km}^{2}\right)$ & Area & \\
\hline & $3.861 \times 10^{-1}$ & square mile \\
\hline liter $(\mathrm{L})$ & Volume & \\
\hline & $2.642 \times 10^{-1}$ & gallon \\
\hline milligram $(\mathrm{mg})$ & Mass & \\
\hline
\end{tabular}

Temperature in degrees Celsius $\left({ }^{\circ} \mathrm{C}\right)$ may be converted to degrees Fahrenheit $\left({ }^{\circ} \mathrm{F}\right)$ by using the following equation:

$$
\left(\mathrm{F}=1.8^{\circ} \mathrm{C}\right)+32 .
$$

Datums

Vertical coordinate information is referenced to the North American Vertical Datum of 1929 (NAVD29).

Horizontal coordinate information is referenced to the North American Datum of 1983 (NAD83).

Abbreviations

\begin{tabular}{ll}
\hline Abbreviation & Meaning \\
\hline$\lambda$ & wavelength \\
$\mu \mathrm{g}$ & microgram \\
$\mu \mathrm{S} / \mathrm{cm}$ & microSeimens per centimeter \\
ADEC & Alaska Department of Environmental Conservation \\
ASC & Alaska Science Center \\
Dis IT & Dissolved incremental titration \\
Dis tot IT & Dissolved total incremental titration \\
Dis fet & Dissolved fixed-end titration \\
DOC & Dissolved Organic Carbon \\
EMAP & Environmental Monitoring and Assessment Program \\
ENRI & Environmental Research Institute \\
ICP-AES & Inductively coupled plasma-atomic emission spectrometric \\
ICP-MS & Inductively coupled plasma-mass spectrometer \\
mL & milliliter \\
NRP & Nation Research Program \\
SUVA & Specific Ultra Violet Absorbance \\
UAA & University of Alaska, Anchorage \\
USEPA & U.S. Environmental Protection Agency \\
USGS & U.S. Geological Survey \\
UV & Ultraviolet-Visible Light \\
UV-Vis & Ultraviolet-Visible Light Absorption Analyses \\
\end{tabular}




\title{
Water Quality in the Tanana River Basin, Alaska, Water Years 2004-06
}

\author{
By Edward H. Moran
}

\section{Overview}

This report contains water-quality data collected from 84 sites in Tanana River basin during water years 2004 through 2006 (October 2003 through September 2006) as part of a cooperative study between the U.S. Geological Survey (USGS) and Alaska Department of Environmental Conservation (ADEC) Alaska Monitoring and Assessment Program (AKMAP), supported in part through the U.S. Environmental Protection Agency (USEPA) Office of Water, Cooperative Assistance Agreement X7-97078801. A broad range of chemical analyses are presented for 93 sets of samples collected at 59 tributaries to the Tanana River and at 25 locations along the mainstem. These data are to provide a means to assess baseline characteristics and establish indicators that are ecologically important, affordable, and relevant to society.

\section{Introduction}

Alaska's water-resource managers are charged to adequately and cost-effectively characterize the status, trends, and needs of the State's waters. Because it is financially impossible to monitor all lakes and streams in Alaska, the use of randomized designs, such as AKMAP, will be critical for developing information to support management decisions and reporting needs. In 2004, a cooperative project between ADEC and USGS began a pilot AKMAP project to evaluate the USEPA Environmental Monitoring and Assessment Program (EMAP) wadeable stream study protocols on the Tanana River Basin in Alaska. The Tanana River originates in the Yukon Territory, Canada, flows west, and discharges into the Yukon River and Tanana, Alaska (fig. 1). The basin covers more than $116,000 \mathrm{~km}^{2}$ and lies south of the Yukon River where discontinuous permafrost has been thawing in recent decades (Jorgenson and others, 2001). Population growth within the basin and along the Tanana River combined with such largescale environmental changes as a result of warming climate may have important consequences for the hydrology and water quality of the Tanana River and its tributaries.
The proposed study area is useful because a wide variety of land uses occur within the unit. These activities include forestry, agriculture, mining, recreation, subsistence, national defense, supporting urban, suburban, and village communities. Federal and State conservation units such as national parks and wildlife refuges also are located in the Tanana River basin.

The USGS assisted ADEC in selecting the sampling sites following USEPA guidelines. Once the sites were selected, the USGS determined basin characteristics such as area and annual precipitation for each site using Geographical Information System (GIS) methods. USGS, ADEC and University of Alaska, Anchorage (UAA) Environmental Research Institute (ENRI) personnel collected water samples from 2004 to 2006. In conjunction with the USGS Yukon River National Stream-Quality Accounting Network program, the sampling parties also obtained water samples at each site for analysis by the USGS NRP. In-situ $\mathrm{pH}$, specific conductance, water temperature and dissolved-oxygen concentrations were measured and samples were analyzed for major ions, dissolved organic carbon, and oxygen isotopes. This report contains the field water-quality constituents and water-quality data analyzed by the USGS for water years 2004-06. The sample-collection methods and the laboratory analytical methods also are described. The AKMAP wadeable stream pilot project also collected separate water-quality parameters, such as nutrients, site flow measurements, stream invertebrate and periphyton collections, and physical habitat data.

\section{Sampling Locations and Subbasin Characteristics}

Due to size of the Tanana River basin, sampling was done over 3 years-water years 2004 to 2006. In 2004 and 2005 , about 30 different sites on wadeable tributary streams to the Tanana River were sampled each year and 25 sites on the mainstem of the Tanana River were sampled in spring 2006 through the ice or open water by snow machine or helicopter (fig. 1, table 1 [at back of report]). 


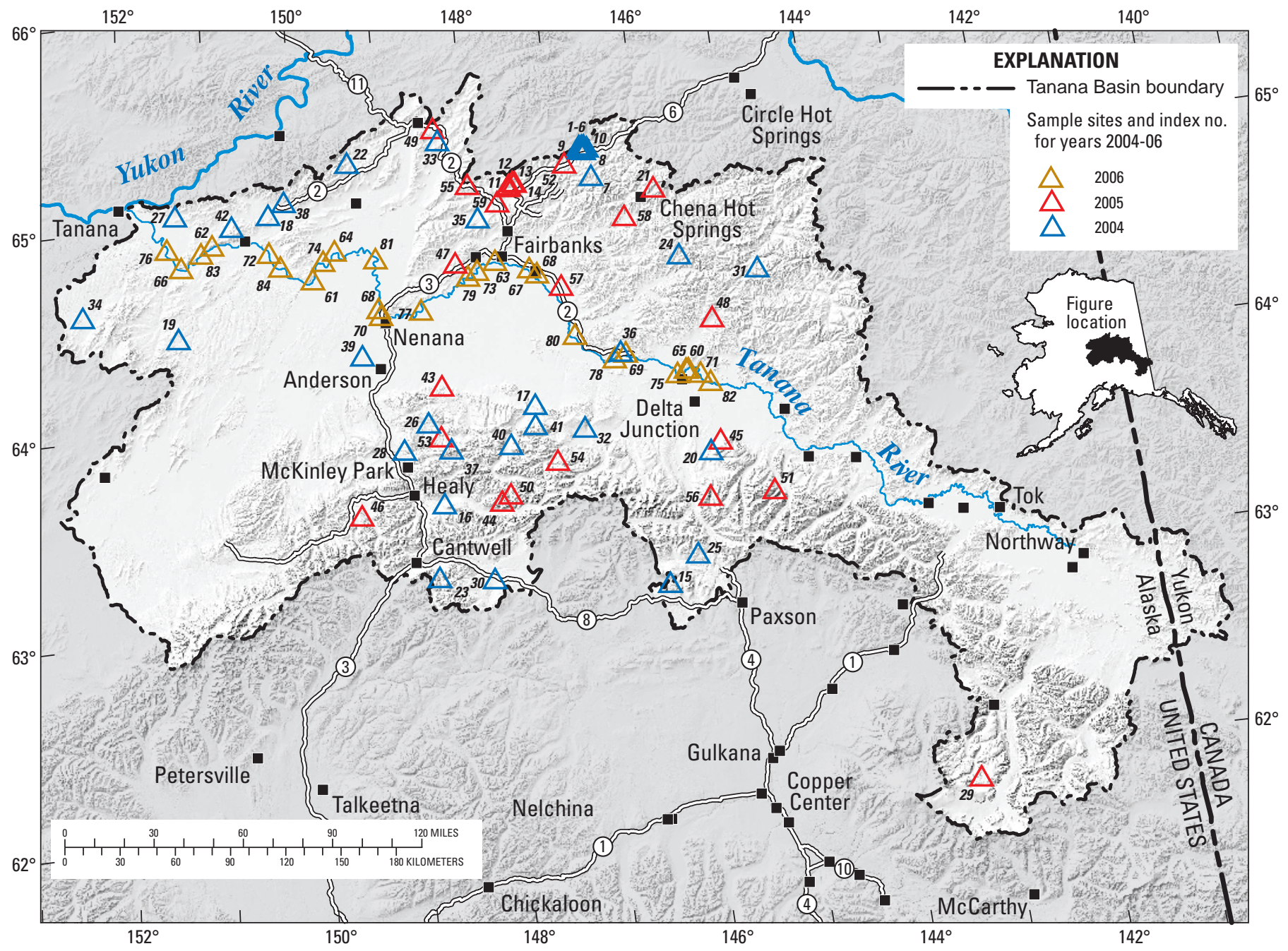

Figure 1. Location of water-quality sampling sites in the Tanana River basin, Alaska.

All sampling locations are in Alaska and altitudes range from 2,064 to $67 \mathrm{~m}$ above North American Vertical Datum of 1929 (NAVD29) (table 2). Subbasins areas range in size from 0.41 to $114,000 \mathrm{~km}^{2}$. Selected sampled subbasin characteristics are provided in table 2 (at back of report).

\section{Water-Quality Data}

ADEC, ENRI, and USGS personnel collected (standard dip-sampling) and processed stream-water quality samples according to established USGS protocols (U.S. Geological Survey, 1997-99) for the USGS samples. Most of the USGS samples were analyzed for dissolved organic carbon and dissolved trace elements because there will be implications for the carbon-cycle trace-element mobility if permafrost continues to thaw in the Tanana River Basin. Additional water samples, in-situ measurements ( $\mathrm{pH}$, dissolved oxygen, specific conductance, and flow), stream macroinvertebrates and periphyton, and physical habitat data were collected at the wadeable stream sites following USEPA EMAP wadeable stream protocols.

The USGS NRP Laboratories in Boulder, Colorado, analyzed all samples for dissolved and whole-water constituents using documented USGS methods and quality-assurance practices (table 3). Data collected during 2004 included laboratory measurements of $\mathrm{pH}$, specific conductance, alkalinity, chloride, nitrate, sulfate, and dissolved organic carbon (DOC) (table 4). In 2005, Specific Ultraviolet-visible Light (UV) Absorbance (SUVA) was added to the list of parameters (table 5). During 2006, the program was expanded to include field measurements of specific conductance and alkalinity and laboratory analysis of water samples for stable isotopes of deuterium and oxygen-18, Ultraviolet-Visible Light Absorption Analyses (UV-Vis), sodium, ammonium, potassium, magnesium, and calcium. The average ionic balance of the 27 samples collected in 2006 varied by less than 2 percent providing a high level of confidence in the accuracy of the data. 


\section{Dissolved Organic Carbon, Specific UV Absorbance, and Ultraviolet-Visible Light Absorption Analyses}

DOC, UV-Vis, and SUVA analyses were filtered in the Fairbanks or Anchorage field office using a $60-\mathrm{mL}$ Becton Dickinson ${ }^{\mathrm{TM}}$ plastic syringe with Luer-lok ${ }^{\mathrm{TM}}$ fitting and a $25-\mathrm{mm}$ Gelman Acrodisk ${ }^{\mathrm{TM}}$ filter with $0.45-\mu \mathrm{m}$ SUPOR ${ }^{\mathrm{TM}}$ membrane into $40-\mathrm{mL}$ baked, brown glass vials with Teflon®-lined caps. These samples were immediately refrigerated and shipped on ice overnight to the USGS NRP laboratories. Samples were refrigerated at the laboratory and analyzed within 2 weeks of arrival. The analytical methods used to determine DOC, UV-Vis, and SUVA are listed in $\underline{\text { table } 3}$ (at back of report). Results are shown in tables $4, \underline{5}$, and $\underline{6}$ (at back of report).

DOC Concentrations.-DOC was measured using the platinum catalysed persulfate wet oxidation method on an O.I. Analytical Model 700 TOC Analyzer ${ }^{\mathrm{TM}}$ (Aiken, 1992). The instrument was warmed up for 24 hours before analyzing samples. Samples and standards were loaded onto an autosampler for analysis and introduced into the reaction vessel by means of a fixed-volume sample loop. The volume of the sample loop was kept small, usually $1 \mathrm{~mL}$, to maintain linear instrument response (0-50 $\mu \mathrm{g}$ of carbon). The standard, automated analytical conditions called for $0.5 \mathrm{~mL}$ of 5 percent by volume phosphoric acid to be added to the sample. The sample was then purged for 2.0 minutes with nitrogen to remove inorganic carbon, after which $0.5 \mathrm{~mL}$ of $0.42 \mathrm{M}$ sodium persulfate solution was added. The standard reaction time of 5 minutes was used for the persulfate oxidation step. The instrument was calibrated with solutions of reagent-grade potassium hydrogen phthalate in distilled water. The standard curve, consisting of a minimum of five standards over the range of interest, was repeated for every eight water samples analyzed in duplicate. Reported values are the averages of duplicate analyses. Standard deviation for the DOC measurement was determined to be $\pm 0.2 \mathrm{mg}$ carbon/L.

Specific UV Absorbance (SUVA).-SUVA, defined as the UV absorbance of a sample measured at a given wavelength $(\lambda)$ divided by the DOC concentration, is an average molar absorptivity for all molecules that comprise the DOC in a water sample. SUVA, therefore, is a parameter that indicates the nature or quality of DOC in a given sample and has been used as a surrogate measurement of DOC aromaticity (Chin and others, 1994). SUVA values at 254 nanometer (nm) $\left(\mathrm{SUVA}_{254}\right)$ are used in this report because (1) natural organic matter absorbs strongly at this wavelength giving increased sensitivity, and (2) strongly correlates with aromatic-carbon content of organic matter. SUVA values are reported as L/(mg carbon $* \mathrm{~m}$ ) and have a standard deviation of \pm 0.1 .
Ultraviolet-Visible Light Absorption Analyses (UV-Vis).-UV-Vis measurements were made on a HewlettPackard Model $8453^{\mathrm{TM}}$ photo-diode array spectrophotometer between $\lambda=200$ and $\lambda=800 \mathrm{~nm}$ with distilled water as the blank utilizing a 1-cm path-length quartz cell. Results are reported for the $\lambda=254 \mathrm{~nm}$ in dimensionless absorbance units. The wavelength of $\lambda=254 \mathrm{~nm}$ was chosen because it is the wavelength commonly associated with the aromatic moieties in a sample (Chin and others, 1994). Samples filtered at room temperature were analyzed using a quartz cell in the manual mode. The cell was rinsed with a small volume of sample before adding sample for analysis. The cell was then rinsed with distilled water before analyzing the next sample. Standard deviation for a UV measurement at $254 \mathrm{~nm}$ is \pm 0.002 angstrom.

\section{Dissolved Trace Metals}

Samples for major ion analyses were filtered in the Fairbanks or Anchorage field office using $60 \mathrm{~mL}$ Becton Dickinson $^{\mathrm{TM}}$ plastic syringes with Luer-lok ${ }^{\mathrm{TM}}$ fittings and a $25-\mathrm{mm}$ Gelman Acrodisk filter with 0.45- $\mu \mathrm{m}$ SUPOR $^{\mathrm{TM}}$ membrane (Babiarz and others, 2000) into clean $125 \mathrm{~mL}$ high density polyethylene bottles. The samples were shipped chilled to the USGS NRP labs in Boulder, CO. Concentrations of major ions were determined by ion chromatography using a Dionex DX120 ion chromatograph ${ }^{\mathrm{TM}}$ (Fishman and Freidman, 1989; Fishman, 1993).

\section{Stable Isotopes of Deuterium and Oxygen-18}

Samples for oxygen-deuterium isotopes were processed at the Fairbanks or Anchorage field office by filling 40-mL baked, clear glass bottles with Poly-Seal ${ }^{\mathrm{TM}}$ caps with sample water leaving no air space. Samples were sent to USGS Isotope laboratory in Reston, VA. Hydrogen-isotope-ratio analyses were performed using a hydrogen equilibration technique (Coplen and others, 1991; Kinga Revesz and Tyler Coplen, U.S. Geological Survey, written commun., 2003). Water samples are measured for $\delta \mathrm{O}^{18}$ using the $\mathrm{CO}_{2}$ equilibration technique of Epstein and Mayeda (1953), which has been automated according to Kinga Revesz and Tyler Coplen (U.S. Geological Survey, written commun., 2003). Therefore, both oxygen and hydrogen isotopic ratio measurements are reported as activities. 


\section{Acknowledgments}

The USGS Alaska Science Center (ASC) thanks Doug Dasher and Teri Lomax of ADEC; Dan Rinella and Dan Bogan of the University of Alaska (UAA) Environment and Natural Resources Institute (ENRI) for collecting water samples; and the USGS National Research Program (NRP) for providing in-kind laboratory services. Additionally, ASC would like to thank NRP scientists Kenna Butler, Tyler Coplen, Jessica Moehle, and Paul Schuster. Without the expertise of contributing individuals, this work would not have been possible.

\section{References Cited}

Aiken, G.R., 1992, Chloride interference in the analysis of dissolved organic carbon by the wet oxidation method: Environmental Science and Technology, v. 26, p. $2435-2439$.

Babiarz, C.L., Hoffman, S.R., Shafer, M.M., Hurley, J.P., Andren, A.W., and Armstrong, D.E., 2000, A critical evaluation of tangential-flow ultrafiltration for trace metal studies in freshwater systems-2 Total mercury and methylmercury: Environmental Science and Technology, v. 34, p. 3428-3434.

Chin, Y., Aiken, G.R., and O’Loughlin, E., 1994, Molecular weight, polydispersity and spectroscopoic properties of aquatic humic substances: Environmental Science and Technology, v. 28, p. 1853-1858.
Coplen, T.B., Wildman, J.D., and Chen, J., 1991, Improvements in the gaseous hydrogen water equilibration technique for hydrogen isotope ratio analysis: Analytical Chemistry, v. 63, p. 910-912.

Epstein, S., and Mayeda, T., 1953, Variation of $\mathrm{O}^{18}$ content of water from natural sources: Geochimica et Cosmochimica Acta, v. 4, p. 213-224.

Ferrians, O.J., 1965, Permafrost map of Alaska: U.S. Geological Survey Miscellaneous Investigation Series Map I-445, scale 1:2,500,000.

Fishman, M.J., 1993, Methods of analysis by the U.S. Geological Survey National Water-Quality LaboratoryDetermination of inorganic and organic constituents in water and fluvial sediments: U.S. Geological Survey Open-File Report 93-125, 217 p.

Fishman, M.J., and Friedman, L.C., 1989, Methods for determination of inorganic substances in water and fluvial sediments: U.S. Geological Survey Techniques of WaterResources Investigations, book 5, chap. A1, 545 p.

Jorgenson, M.T., Racine, C.H., Walters, J.C., and Osterkamp, T.E., 2001, Widespread and rapid permafrost degradation and associated ecological changes caused by a warming climate on the Tanana Flats, Central Alaska: Climatic Change, v. 48, p. 551-579.

U.S. Geological Survey, 1997-1999, National field manual for the collection of water-quality data: U.S. Geological Survey Techniques of Water-Resources Investigations, book 9, chaps, A1-A9, 2 v., variously paged. [Chapters were published from 1997 to 1999; updates and revisions are ongoing and can be viewed at: http://water.usgs.gov/owq/ FieldManual/mastererrata.html]. 


\section{Tables}

The tables distributed with this report are Microsoft Excel® spreadsheets and are available at URL: http://pubs.usgs.gov/of/2007/1390.

Table 1. Summary of site characteristics at sampling locations in the Tanana River basin, Alaska.

Table 2. Basin characteristics of sampled subbasins in the Tanana River basin, Alaska.

Table 3. Summary of standard analytical methods and references.

Table 4. Water-quality data for sites sampled in 2004 in the Tanana River basin, Alaska.

Table 5. Water-quality data for sites sampled in 2005 in the Tanana River basin, Alaska.

Table 6. Water-quality data for sites sampled in 2006 in the Tanana River basin, Alaska. 
Water Quality in the Tanana River Basin, Alaska, Water Years 2004-06

This page intentionally left blank. 
Manuscript approved for publication, November 5, 2007

Prepared by the USGS Publishing Network,

Publishing Service Center, Tacoma, Washington

Bill Gibbs

Bobbie Jo Richey

Sharon Wahlstrom

For more information concerning the research in this report, contact the Director, Alaska Science Center

U.S. Geological Survey, 4230 University Dr., Suite 201

Anchorage, AK 99508-4650

http://alaska.usgs.gov 


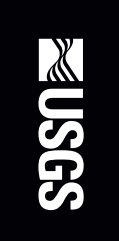

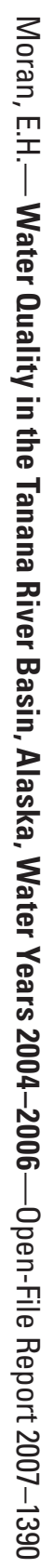

